Original Research

\title{
Development of the Flash Ironmaking Technology (FIT) for Green Ironmaking with Low Energy Consumption
}

\author{
Hong Yong Sohn *, Mohamed Elzohiery, De-Qiu Fan
}

Department of Materials Science \& Engineering, University of Utah, Salt Lake City, Utah 84112-0114, U.S.A.; E-Mails: h.y.sohn@utah.edu; mohamed.elzohiery@gmail.com; jerrydqfan@gmail.com

* Correspondence: Hong Yong Sohn; E-Mail: h.y.y.sohn@utah.edu

Academic Editors: Francesco Gabriele Galizia and Marco Bortolini

Special Issue: Energy Efficiency in Flexible and Reconfigurable Manufacturing: Emerging Trends, Models and Applications in the Industry 4.0 Era

Journal of Energy and Power Technology

2021, volume 3 , issue 3

doi:10.21926/jept.2103042
Received: June 28, 2021

Accepted: September 14, 2021

Published: September 23, 2021

\begin{abstract}
This article describes the development of a novel ironmaking technology based on flash reduction. The development started with the proof of the kinetic feasibility, considering that a typical flash reactor provides only a few seconds of residence time. This was followed by tests in a laboratory flash reactor and finally a pilot plant operation. The rate equations formulated in this work were developed considering the optimum combination of temperature, residence time, and reducing gas partial pressure to achieve $>95 \%$ reduction degree. Experiments in the intermediate-scale laboratory flash reactor indicated that more than $90 \%$ reduction degree could be obtained in a few second residence time at temperature as low as $1175{ }^{\circ} \mathrm{C}$. A pilot reactor operating at $1200-1550{ }^{\circ} \mathrm{C}$ was installed and run to collect data necessary for scaling up the process. The tests in this large reactor validated the design concept in terms of heat supply and residence time, and identified technical hurdles. This investigation proved the technical feasibility of the flash ironmaking technology. The results of this work will facilitate the design for the industrial flash ironmaking reactor. The novel technology is expected to decrease the energy consumption in ironmaking by up to $44 \%$ compared with the average blast furnace process, and will reduce $\mathrm{CO}_{2}$ emissions by up to $51 \%$.
\end{abstract}

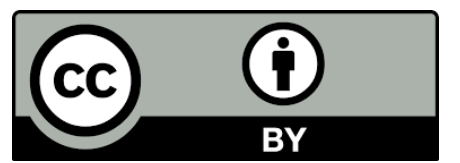

(C) 2021 by the author. This is an open access article distributed under the conditions of the Creative Commons by Attribution License, which permits unrestricted use, distribution, and reproduction in any medium or format, provided the original work is correctly cited. 
When hydrogen is used, the proposed process would use up to $60 \%$ less energy with little carbon dioxide emissions. However, it is noted that the energy requirements and $\mathrm{CO}_{2}$ emissions during the production of natural gas, hydrogen or coal must be added for a comprehensive comparison.

\section{Keywords}

Flash Ironmaking Technology (FIT); CFD design; flash reactor; pilot reactor; magnetite; concentrate; reduction kinetics; hydrogen; natural gas; blast furnace; carbon dioxide; energy consumption; greenhouse gas

\section{Introduction}

This paper describes the development of the novel Flash Ironmaking Technology (FIT) [1], which is based on the reduction of iron oxide concentrates by gas in a flash reactor. The development of the novel process also includes two of the most serious aspects in steelmaking, i.e. carbon dioxide emissions and energy consumption. The steel industry contributes around $6 \sim 7 \%$ of the total anthropogenic emissions of carbon dioxide [2].

Worldwide, the blast furnace process currently produces more than $90 \%$ of iron, while the rest is produced by the Direct Reduction processes [3]. The blast furnace process needs the solid charge to be sinters or pellets and coke. The production of these two solid charges, which are eliminated in the proposed process described in this paper, requires much energy and is pollution-prone.

Two general groups of gas-based alternate technologies for making iron have been developed: shaft furnace processes [4] and fluidized-bed processes [5-7]. These technologies, however, are not sufficiently intensive to compete with the blast furnace, for they cannot be operated at high temperatures because of the sticking problems.

Therefore, a novel Flash Ironmaking Technology (FIT) by which iron is produced directly from concentrates by a flash reduction process has been developed. This new technology utilizes hydrogen or natural gas as a fuel as well as reducing agent. It does not require pellets, sinters or coke [1, 8-10]. Furthermore, iron ore concentrate that would be used in a FIT reactor is currently produced in large quantities from taconite ore in the U.S. [11].

In this article, the development of the novel ironmaking process is described starting from the kinetic feasibility determination to the laboratory flash furnace work and finally the tests in a pilot plant. Process simulation and economic analysis on the new process [12-15] is also summarized.

\section{Description of the Flash Ironmaking Technology (FIT)}

A sketch of the Flash Ironmaking process is shown in Figure 1. A gaseous fuel is partially oxidized with industrial oxygen to generate a reducing gas at $1600-1900 \mathrm{~K}$. Iron ore concentrate is fed from the top, and the reduced iron product can be collected as a solid powder or as a molten bath for direct steelmaking.

Natural gas is also plentiful in the U.S. and could easily supply potential ironmaking based on the FIT [16]. Hydrogen would be cleaner once the hydrogen economy is developed $[17,18]$. On the other 
hand, the application of hydrogen to ironmaking would provide a large market for hydrogen, thus facilitating its development.

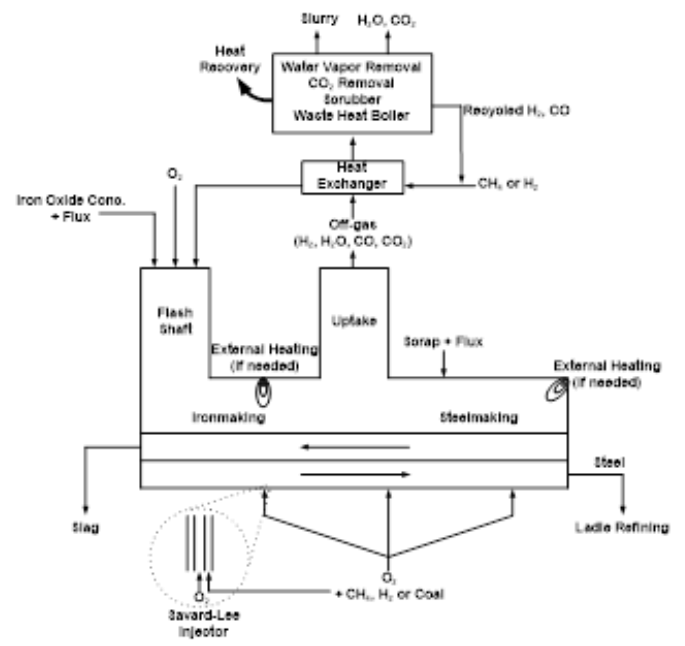

Figure $1 \mathrm{~A}$ sketch of a direct steelmaking process based on the Flash Ironmaking Technology (FIT). [Adapted from M. Elzohiery, Flash Reduction of Magnetite Concentrate Related to a Novel Flash Ironmaking Process, Ph.D. Dissertation, Salt Lake City, Utah: University of Utah, 2018.]

The development of the FIT started with the establishment of sufficient kinetic feasibility, considering the fact that there are only a few seconds of residence time available in a typical flash reactor. Upon the establishment of the kinetic feasibility, a laboratory flash reactor was tested, which was followed by a pilot-scale reactor test program.

\section{Reduction Kinetics of Magnetite Concentrate Particles}

Magnetite concentrate from a taconite ore of the Mesabi Range was used in this study, the chemical composition of which is presented in Table 1.

Table 1 Chemical composition (wt\%) of magnetite concentrate.

\begin{tabular}{llll}
\hline \multirow{2}{*}{ Component } & \multicolumn{3}{l}{$\mathbf{W t} \%$ in Samples in the designated particle size range } \\
& $\mathbf{2 0 - 2 5} \boldsymbol{\mu m}$ & $\mathbf{3 2 - 3 8} \boldsymbol{\mu m}$ & $\mathbf{4 5 - 5 3} \boldsymbol{\mu m}$ \\
\hline Total Fe & 71.0 & 70.3 & 67.6 \\
$\mathrm{FeO}$ & 30.6 & 30.2 & 29.7 \\
$\mathbf{S}$ & 0.02 & 0.02 & 0.02 \\
$\mathrm{C}$ & 0.25 & 0.28 & 0.58 \\
$\mathrm{SiO}_{2}$ & 1.68 & 2.08 & 4.51 \\
$\mathrm{Al}_{2} \mathrm{O}_{3}$ & 0.13 & 0.10 & 0.17 \\
$\mathrm{CaO}$ & 0.21 & 0.35 & 0.85 \\
$\mathrm{MgO}$ & 0.11 & 0.18 & 0.49 \\
$\mathrm{MnO}$ & 0.09 & 0.12 & 0.24 \\
$\mathrm{Cr}_{2} \mathrm{O}_{3}$ & 0.10 & 0.07 & 0.11 \\
$\mathrm{Na}_{2} \mathrm{O}$ & 0.10 & 0.10 & 0.10 \\
\hline
\end{tabular}


Sohn and coworkers [19-24] have studied the reduction rates of magnetite concentrate under the conditions of the FIT. The results were expressed by the following equation for component gases $\mathrm{H}_{2}$ or $\mathrm{CO}$ :

$$
\left.\frac{d X}{d t}\right|_{j}=k_{j} \cdot\left[p_{j}^{m_{j}}-\left(\frac{p_{j O}}{K_{j}}\right)^{m_{j}}\right] \cdot n_{j}(1-X)[-\operatorname{Ln}(1-X)]^{1-\frac{1}{n_{j}}} \cdot d_{p}^{-s_{j}} ; j=H_{2} \text { or CO }
$$

where $k_{j}$ is the reaction rate constant for gas $j, k_{j}=k_{o, j} \exp \left(-\frac{E_{j}}{R T}\right) ; p_{j}$ is the partial pressure of gas $j ; K_{j}$ is the equilibrium constant for the reduction of $\mathrm{FeO}$ by gas $j ; m_{j}$ is the reaction order with respect to gas $j ; n_{j}$ is the Avrami parameter; $d_{p}^{-s_{j}}$ is the particle size dependence; $X$ is the fraction of the total removable oxygen in the concentrate particles removed by the reaction.

The relevant kinetic parameters are given in Table 2 . The reader is referred to the original papers $[19,20,23,24]$ for other details of the rate measurements and data analyses.

Table 2 Kinetic Parameters for Reduction of Magnetite Concentrate by Each Component Gas [19, 20, 23, 24].

\begin{tabular}{lllllll}
\hline Reducing Gas, $\boldsymbol{j}$ & Temperature Range & $\boldsymbol{k}_{\boldsymbol{o}, \boldsymbol{j}}$ & $\boldsymbol{E}_{\boldsymbol{j}}(\mathbf{k J} / \mathrm{mol})$ & $\boldsymbol{m}_{\boldsymbol{j}}$ & $\boldsymbol{n}_{\boldsymbol{j}}$ & $\boldsymbol{s}_{\boldsymbol{j}}$ \\
\hline \multirow{2}{*}{$\mathrm{H}_{2}$} & $1423-1623 \mathrm{~K}$ & $1.23 \times 10^{7} \mathrm{~atm}^{-1} \mathrm{~s}^{-1}$ & 196 & 1 & 1 & 0 \\
& $1623-1873 \mathrm{~K}$ & $6.07 \times 10^{7} \mathrm{~atm}^{-1} \cdot \mathrm{s}^{-1} \cdot \mu \mathrm{m}$ & 180 & 1 & 1 & 1 \\
$\mathrm{H} \mathrm{CO}$ & $1423-1623 \mathrm{~K}$ & $1.07 \times 10^{14} \mathrm{~atm}^{-1} \mathrm{~s}^{-1}$ & 451 & 1 & 0.5 & 0 \\
& $1623-1873 \mathrm{~K}$ & $6.45 \times 10^{3} \mathrm{~atm}^{-1} \cdot \mathrm{s}^{-1} \cdot \mu \mathrm{m}$ & 88 & 1 & 0.5 & 1 \\
\hline
\end{tabular}

When magnetite concentrate is reduced by a mixture of $\mathrm{H}_{2}+\mathrm{CO}$, the $\mathrm{CO}$ enhances the rate of reaction between $\mathrm{H}_{2}$ and iron oxide. This is most likely due to the effect of $\mathrm{CO}$ on the morphology of the reduced iron by forming whiskers, which was observed in a separate study [25]. Taking this into consideration, Fan et al. [20] developed the following rate expression:

The complete rate equations for magnetite concentrate reduction by a $\mathrm{H}_{2}+\mathrm{CO}$ mixture at $1423 \mathrm{~K}$ $\left(1150{ }^{\circ} \mathrm{C}\right)-1623 \mathrm{~K}\left(1350^{\circ} \mathrm{C}\right)$ and $1623 \mathrm{~K}\left(1350^{\circ} \mathrm{C}\right)-1873 \mathrm{~K}\left(1600^{\circ} \mathrm{C}\right)$ are given, respectively, as:

$$
\begin{gathered}
\frac{d X}{d t}=\left.\left(1+1.3 \cdot \frac{p_{c o}}{p_{c o}+p_{H_{2}}}\right) \cdot \frac{d X}{d t}\right|_{H_{2}}+\left.\frac{d X}{d t}\right|_{C O} 1423 \mathrm{~K}<T<1623 \mathrm{~K} \\
\frac{d X}{d t}=\left.\left[1+(-0.01 T+19.65) \cdot \frac{p_{c o}}{p_{c o}+p_{H_{2}}}\right] \cdot \frac{d X}{d t}\right|_{H_{2}}+\left.\frac{d X}{d t}\right|_{C O} 1623 \mathrm{~K}<T<1873 \mathrm{~K}
\end{gathered}
$$

where $\left.\frac{d X}{d t}\right|_{\mathrm{H}_{2}}$ and $\left.\frac{d X}{d t}\right|_{C O}$ represent the rates of reduction individually by $\mathrm{H}_{2}$ and CO, respectively, obtained from Eq. (1) with the parameters listed in Table 2.

These kinetics measurements confirmed the fact that a few seconds of residence time in a flash reactor at temperatures of $1473 \mathrm{~K}$ or higher are sufficient to reduce iron ore concentrate.

\section{Tests in a Laboratory Flash Reactor}

After verifying the sufficiently rapid kinetics of the reduction, experiments on flash ironmaking were conducted in a laboratory flash reactor shown in Figure $2[8,26,27]$. The reactor was made of 
steel. A uniform temperature zone was maintained at $1175 \pm 25^{\circ} \mathrm{C}$ by the partial oxidation of methane and/or hydrogen with oxygen. Methane was used here to represent natural gas that is likely to be used in industry, which is largely made up of methane. The heating was augmented by electrical heating. The partial oxidation of methane generated $\mathrm{H}_{2}+\mathrm{CO}$ [26-29].
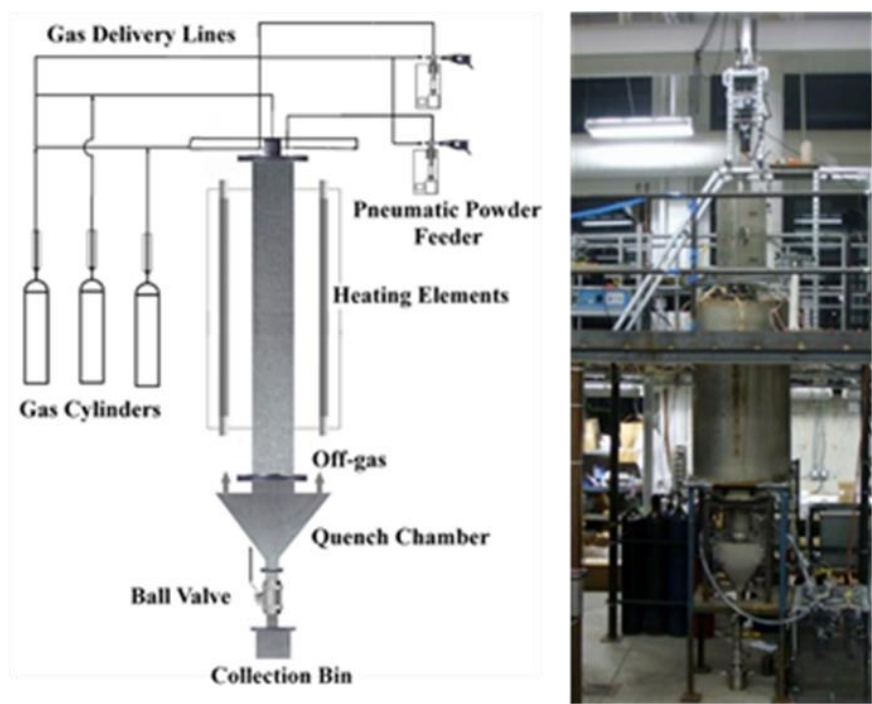

Figure 2 The Utah laboratory flash ironmaking reactor (I.D. $0.19 \mathrm{~m}$ and height $2.13 \mathrm{~m}$ ).

\subsection{Particle Feeding Mode}

Figure 3 shows two feeding configurations: (a) through the burner; (b) through 2 separate holes away from the burner.

(a)

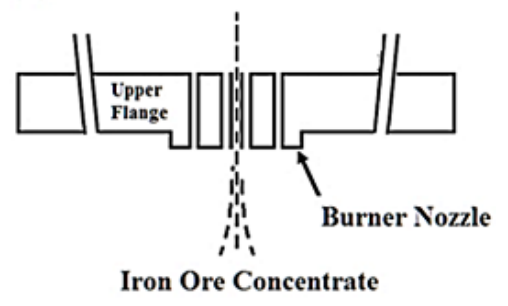

(b)

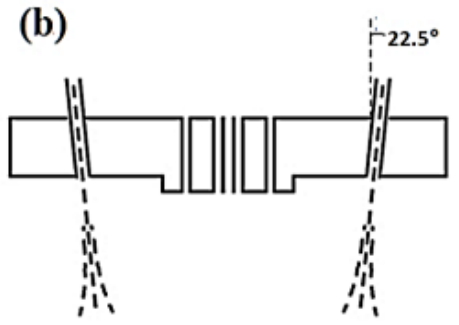

Figure 3 Powder feeding configurations: (a) through the burner (B), (b) through two separate holes on the side of the burner (SS). [Adapted from M. Elzohiery, Flash Reduction of Magnetite Concentrate Related to a Novel Flash Ironmaking Process, Ph.D. Dissertation, Salt Lake City, Utah: University of Utah, 2018.] 


\subsection{Flame Configuration}

The burner consisted of a nozzle, shown in Figure 4, made of Inconel. Two flame configurations were tested by exchanging the oxygen and fuel feeding ports. In the $\mathrm{F}-\mathrm{O}-\mathrm{F}$ configuration $(\mathrm{H}-\mathrm{O}-\mathrm{H}$ when hydrogen was the fuel), the fuel was fed through Slot 1 and surrounded the oxygen fed through Slot 2. In the O-F-O configuration, oxygen was fed through Slot 1 surrounding the fuel fed through Slot 2. These changes in the burner configuration affected the temperature profile in the reactor. Figure 5 shows the different temperature distributions in the cases of hydrogen as the fuel in $(a, b)$ and methane as the fuel in (c, d) simulated using CFD analysis [27].

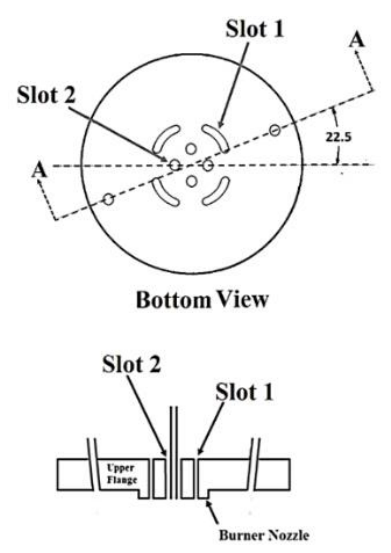

Section A-A

Figure 4 Sketch of the fuel/oxygen burner: (a) Plan view showing the configuration of the slots, (b) injection ports at section (A-A). [Adapted from M. Elzohiery, Flash Reduction of Magnetite Concentrate Related to a Novel Flash Ironmaking Process, Ph.D. Dissertation, Salt Lake City, Utah: University of Utah, 2018.]

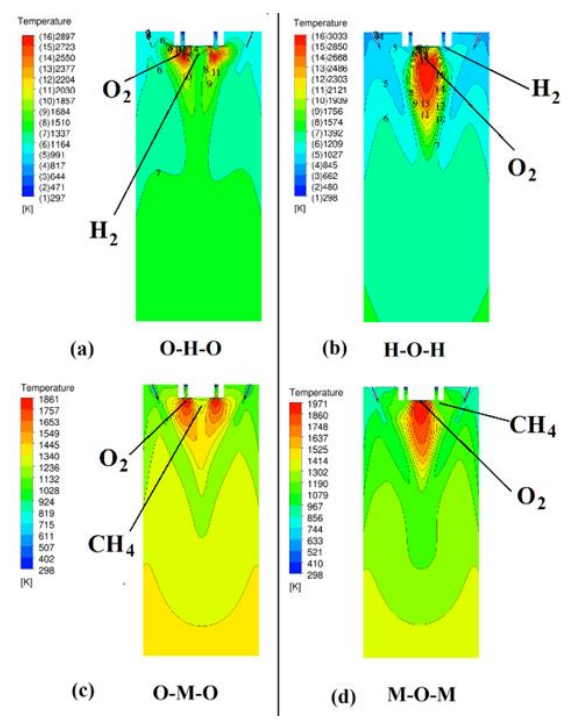

Figure 5 Temperature profile in the reactor with hydrogen as the fuel in (a) $\mathrm{O}-\mathrm{H}-\mathrm{O}$, (b) $\mathrm{H}-\mathrm{O}-\mathrm{H}$; and with methane as the fuel in (c) O-F-O, and (d) F-O-F. [Adapted from M. Elzohiery, D.-Q. Fan, Y. Mohassab, and H. Y. Sohn, Metall. Mater. Trans. B, 51, 1003 (2020). https://doi.org/10.1007/s11663-020-01809-9]. 


\subsection{Experiments with Hydrogen}

A high-temperature mixture of hydrogen and water vapor, with a sufficient reducing power for iron oxide, was generated from the partial oxidation of hydrogen. A reduction degree greater than $90 \%$ was achieved with some excess hydrogen in a few seconds of residence time at a temperature as low as $1175^{\circ} \mathrm{C}$. The reactor was made of a steel tube and thus this temperature was the maximum wall temperature that could be reached in this laboratory flash furnace. The experimental data are presented in Table 3. Figure 6 shows the extent of reduction as a function of reaction time and the Excess Driving Force (EDF). Here, EDF denotes the excess $\mathrm{H}_{2}$ present in the gas above the equilibrium level, defined as follows:

$$
E D F=\frac{\frac{p_{H_{2}}}{p_{H_{2} O}}-\frac{p_{H_{2, e q}}}{p_{H_{2} O, e q}}}{\frac{p_{H_{2, e q}}}{p_{H_{2} O, e q}}}
$$

Table 3 The conditions and results of experiments with hydrogen in the laboratory flash reactor.

\begin{tabular}{|c|c|c|c|c|c|c|c|}
\hline \multicolumn{3}{|c|}{ Gases Flow rate (L/m) } & \multirow{2}{*}{$\begin{array}{l}\text { Conc. Feeding Rate } \\
(\mathrm{g} / \mathrm{m})\end{array}$} & \multirow{2}{*}{ Feeding Mode } & \multirow{2}{*}{ Flame Config. } & \multirow{2}{*}{ EDF } & \multirow{2}{*}{ RD (\% } \\
\hline $\mathrm{H}_{2}$ & $\mathrm{O}_{2}$ & $\mathbf{N}_{\mathbf{2}}$ & & & & & \\
\hline \multirow{6}{*}{15.3} & 2.16 & 2.80 & 1.9 & SS & $\mathrm{H}-\mathrm{O}-\mathrm{H}$ & 0.5 & 82 \\
\hline & 2.16 & 2.80 & 1.8 & SS & $\mathrm{O}-\mathrm{H}-\mathrm{O}$ & 0.5 & 99 \\
\hline & 2.36 & 2.80 & 1.7 & SS & $\mathrm{H}-\mathrm{O}-\mathrm{H}$ & 0.4 & 76 \\
\hline & 2.48 & 2.80 & 2.0 & SS & $\mathrm{H}-\mathrm{O}-\mathrm{H}$ & 0.2 & 70 \\
\hline & 2.50 & 2.80 & 1.9 & SS & $\mathrm{H}-\mathrm{O}-\mathrm{H}$ & 0.2 & 70 \\
\hline & 2.72 & 2.80 & 2.1 & SS & $\mathrm{H}-\mathrm{O}-\mathrm{H}$ & 0.06 & 57 \\
\hline \multirow{7}{*}{20.0} & 2.20 & 2.80 & 2.2 & SS & $\mathrm{H}-\mathrm{O}-\mathrm{H}$ & 1.1 & 96 \\
\hline & 2.90 & 1.85 & 2.0 & $B$ & $\mathrm{H}-\mathrm{O}-\mathrm{H}$ & 0.5 & 26 \\
\hline & 2.90 & 2.00 & 1.7 & B & $\mathrm{O}-\mathrm{H}-\mathrm{O}$ & 0.5 & 44 \\
\hline & 2.96 & 2.80 & 1.8 & SS & $\mathrm{H}-\mathrm{O}-\mathrm{H}$ & 0.5 & 84 \\
\hline & 2.96 & 2.80 & 2.2 & SS & $\mathrm{H}-\mathrm{O}-\mathrm{H}$ & 0.5 & 80 \\
\hline & 3.22 & 2.80 & 1.9 & SS & $\mathrm{H}-\mathrm{O}-\mathrm{H}$ & 0.3 & 80 \\
\hline & 3.70 & 2.80 & 2.0 & SS & $\mathrm{H}-\mathrm{O}-\mathrm{H}$ & 0.1 & 63 \\
\hline \multirow[t]{2}{*}{36.0} & 5.60 & 1.85 & 2.0 & $B$ & $\mathrm{H}-\mathrm{O}-\mathrm{H}$ & 0.5 & 46 \\
\hline & 4.32 & 2.80 & 2.2 & SS & $\mathrm{H}-\mathrm{O}-\mathrm{H}$ & 1.4 & 92 \\
\hline \multirow{3}{*}{40.0} & 6.40 & 2.80 & 2.1 & SS & $\mathrm{H}-\mathrm{O}-\mathrm{H}$ & 0.5 & 77 \\
\hline & 6.40 & 2.80 & 1.9 & SS & $\mathrm{O}-\mathrm{H}-\mathrm{O}$ & 0.5 & 90 \\
\hline & 6.40 & 2.80 & 2.3 & SS & $\mathrm{O}-\mathrm{H}-\mathrm{O}$ & 0.5 & 87 \\
\hline \multirow{5}{*}{60.0} & 7.83 & 1.85 & 1.9 & $B$ & $\mathrm{H}-\mathrm{O}-\mathrm{H}$ & 1.0 & 59 \\
\hline & 9.65 & 2.80 & 1.9 & SS & $\mathrm{H}-\mathrm{O}-\mathrm{H}$ & 0.5 & 74 \\
\hline & 9.65 & 1.85 & 2.0 & $B$ & $\mathrm{H}-\mathrm{O}-\mathrm{H}$ & 0.5 & 53 \\
\hline & 9.65 & 1.85 & 2.0 & B & $\mathrm{H}-\mathrm{O}-\mathrm{H}$ & 0.5 & 59 \\
\hline & 9.65 & 1.85 & 1.5 & B & $\mathrm{O}-\mathrm{H}-\mathrm{O}$ & 0.5 & 75 \\
\hline
\end{tabular}




\begin{tabular}{lllllll}
\hline 9.65 & 2.80 & 2.1 & SS & $\mathrm{O}-\mathrm{H}-\mathrm{O}$ & 0.5 & 83 \\
9.65 & 2.80 & 2.2 & SS & $\mathrm{H}-\mathrm{O}-\mathrm{H}$ & 0.5 & 74 \\
10.1 & 2.80 & 1.67 & SS & $\mathrm{H}-\mathrm{O}-\mathrm{H}$ & 0.3 & 69 \\
10.65 & 2.80 & 2.3 & SS & $\mathrm{H}-\mathrm{O}-\mathrm{H}$ & 0.3 & 72 \\
11.2 & 2.80 & 2.0 & SS & $\mathrm{H}-\mathrm{O}-\mathrm{H}$ & 0.2 & 64 \\
11.2 & 2.80 & 2.0 & SS & $\mathrm{H}-\mathrm{O}-\mathrm{H}$ & 0.2 & 65 \\
11.2 & 2.00 & 2.0 & B & $\mathrm{O}-\mathrm{H}-\mathrm{O}$ & 0.2 & 58 \\
12.2 & 2.80 & 2.0 & SS & $\mathrm{H}-\mathrm{O}-\mathrm{H}$ & 0.06 & 49 \\
\hline
\end{tabular}

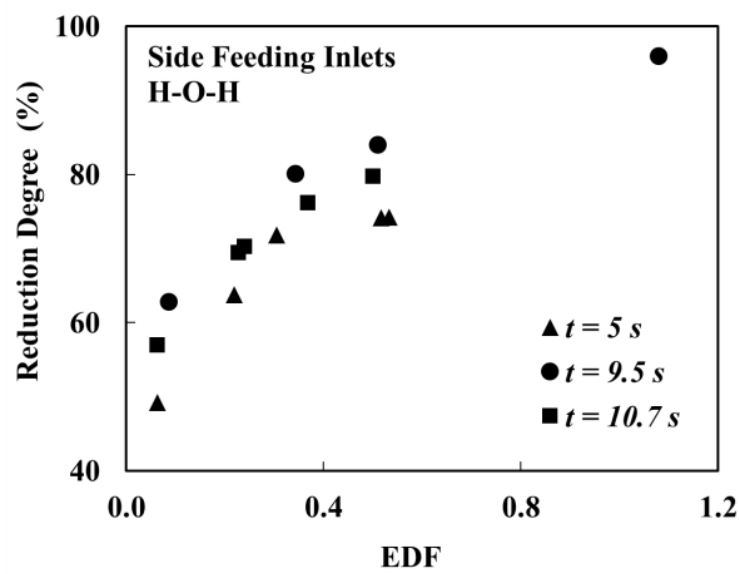

Figure 6 Effect of EDF and particle residence time on \% reduction with concentrate fed through the two side holes and $\mathrm{H}-\mathrm{O}-\mathrm{H}$ flame configuration. [Adapted from M. Elzohiery, Flash Reduction of Magnetite Concentrate Related to a Novel Flash Ironmaking Process, Ph.D. Dissertation, Salt Lake City, Utah: University of Utah, 2018.]

The $\mathrm{H}-\mathrm{O}-\mathrm{H}$ flame configuration had a high flame temperature $\left(\sim 2624{ }^{\circ} \mathrm{C}\right.$ calculated by CFD) as shown in Figure 5 . When fed through the flame in the $\mathrm{H}-\mathrm{O}-\mathrm{H}$ configuration, the particles melted in the flame into round particles. Melting decreases the surface area compared with side feeding in which the particles retain their irregular shape, as shown in Figure 7.

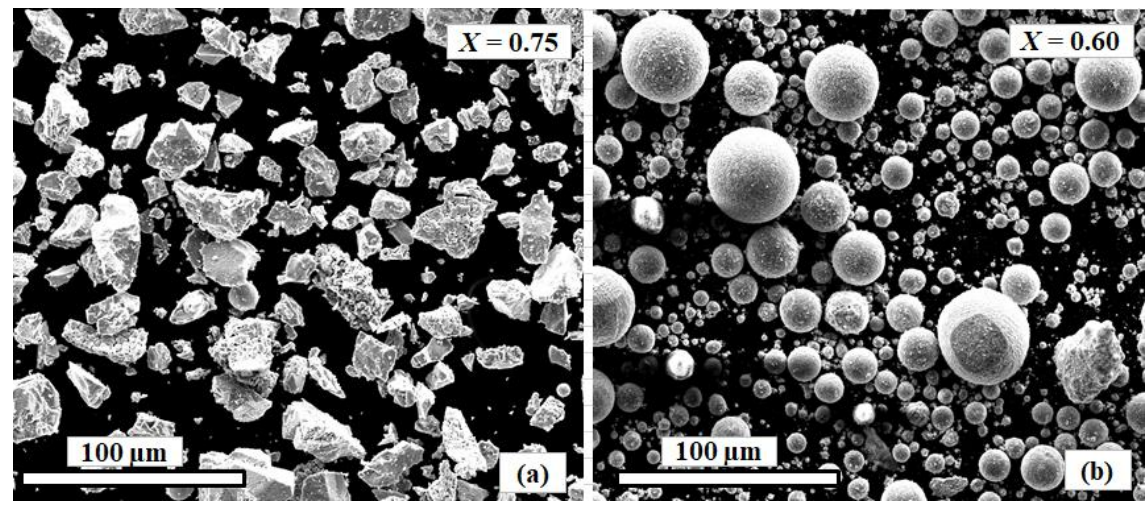

Figure $7 \mathrm{SEM}$ micrographs of the samples from runs with $60 \mathrm{~L} / \mathrm{min}_{2}$ and $9.65 \mathrm{~L} / \mathrm{min} \mathrm{O}_{2}$ and EDF $=0.5$ : (a) fed from the side and (b) fed through the burner. [Adapted from $\mathrm{M}$. Elzohiery, Flash Reduction of Magnetite Concentrate Related to a Novel Flash Ironmaking Process, Ph.D. Dissertation, Salt Lake City, Utah: University of Utah, 2018. 
The temperature in the center of the flame with the $\mathrm{O}-\mathrm{H}-\mathrm{O}$ flame configuration was lower than that in the case of $\mathrm{H}-\mathrm{O}-\mathrm{H}$ flame, $1234{ }^{\circ} \mathrm{C}$ and $2624{ }^{\circ} \mathrm{C}$, respectively. Therefore, particles retained their irregular shape and were reduced more rapidly. Figure 8 shows the particle shapes in the cases of different flame configurations.

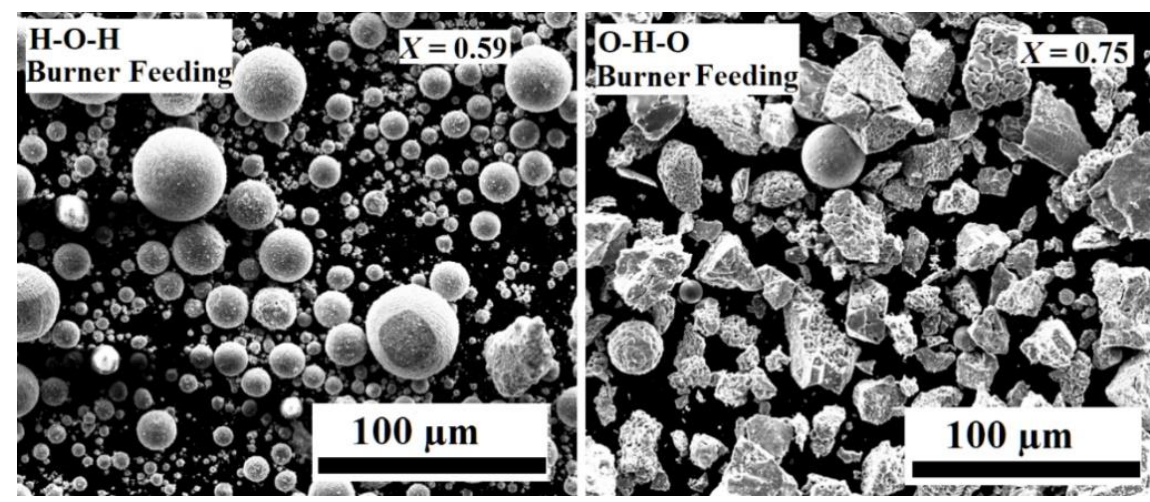

Figure $8 \mathrm{SEM}$ micrographs of the particles from runs with $60 \mathrm{~L} / \mathrm{min} \mathrm{H}_{2}$ and $9.65 \mathrm{~L} / \mathrm{min}$ $\mathrm{O}_{2}$, with particles fed through the burner in (a) H-O-H (RD\% $\left.=59 \%\right)$ [same as 7b] and (b) $\mathrm{O}-\mathrm{H}-\mathrm{O}(\mathrm{RD} \%=75 \%)$ flame configurations. [Adapted from M. Elzohiery, Flash Reduction of Magnetite Concentrate Related to a Novel Flash Ironmaking Process, Ph.D. Dissertation, Salt Lake City, Utah: University of Utah, 2018.

When the particles are fed through the side holes, they experience higher temperatures in the $\mathrm{O}-\mathrm{H}-\mathrm{O}$ flame than in the $\mathrm{H}-\mathrm{O}-\mathrm{H}$ configuration (Figure 5), and thus react faster, as shown in Figure 9.

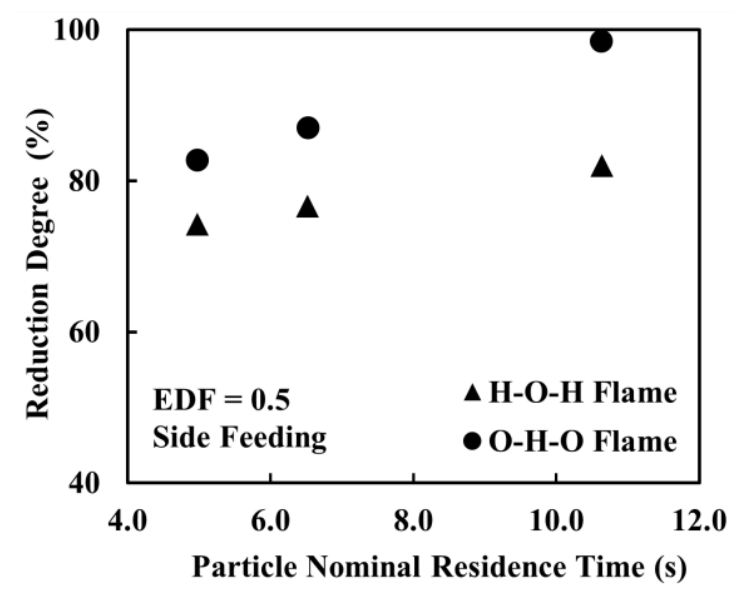

Figure 9 Effect of flame configuration on \% reduction at EDF $=0.5$ with particles fed through the side feeding ports. [Adapted from M. Elzohiery, Flash Reduction of Magnetite Concentrate Related to a Novel Flash Ironmaking Process, Ph.D. Dissertation, Salt Lake City, Utah: University of Utah, 2018.]

\subsection{Experiments with Methane}

The laboratory flash reactor was also operated by partially combusting methane gas with pure oxygen, which produced heat and a gas mixture of $\mathrm{H}_{2}+\mathrm{CO}+\mathrm{H}_{2} \mathrm{O}+\mathrm{CO}_{2}$ [28]. Hydrogen was fed with methane gas to help stabilize the flame. When only methane was injected, the flame was unstable 
under the partial oxidation conditions and soot was formed at the burner nozzle and the top part of the reactor. Further, in an industrial flash furnace, the injected fuel and reductant gas should be natural gas mixed with the recycled hydrogen recovered from the off-gas, considering the fact that the off-gas must contain a significant amount of hydrogen even at the equilibrium condition. The tested flowrate of hydrogen was varied from 0.1 to $2 \mathrm{~L} / \mathrm{min}$.

The temperature in the flame in the methane experiments was lower than in the hydrogen experiments, as shown in Figure 5, and this also contributes to the lower reduction degree with methane.

The residence time was calculated based on the measured temperature profile. Table 4 lists the experimental conditions. A reduction degree of $80 \pm 5 \%$ was obtained at EDF $=1$ based on hydrogen content and particle residence time of 8 seconds even at the low temperature of $1175^{\circ} \mathrm{C}$.

Table 4 The conditions and results of the experiments performed with methane in the laboratory flash reactor.

\begin{tabular}{|c|c|c|c|c|c|c|c|c|}
\hline \multicolumn{4}{|c|}{$\begin{array}{l}\text { Gases Flow Rate } \\
\text { (L/min) }\end{array}$} & \multirow{2}{*}{$\begin{array}{l}\text { Conc. Feeding Rate } \\
\text { (g/min) }\end{array}$} & \multirow{2}{*}{ Feeding Mode } & \multirow{2}{*}{ Flame Config. } & \multirow{2}{*}{$\begin{array}{l}\mathrm{H}_{2} \\
\text { EDF }\end{array}$} & \multirow{2}{*}{$\begin{array}{l}\text { Exp. RD } \\
\text { (\%) }\end{array}$} \\
\hline $\mathrm{CH}_{4}$ & $\mathrm{H}_{2}$ & $\mathrm{O}_{2}$ & $\mathbf{N}_{2}$ & & & & & \\
\hline \multirow{13}{*}{5.0} & \multirow{7}{*}{2.0} & 4.0 & 2.8 & 2.0 & SS & O-F-O & 1.1 & 83 \\
\hline & & 4.0 & 2.8 & 2.4 & SS & $\mathrm{F}-\mathrm{O}-\mathrm{F}$ & 1.1 & 76 \\
\hline & & 4.5 & 2.8 & 2.0 & SS & $\mathrm{F}-\mathrm{O}-\mathrm{F}$ & 0.5 & 64 \\
\hline & & 4.5 & 2.8 & 1.8 & SS & O-F-O & 0.5 & 72 \\
\hline & & 4.0 & 2.0 & 1.9 & $B$ & $\mathrm{O}-\mathrm{F}-\mathrm{O}$ & 1.1 & 83 \\
\hline & & 4.0 & 2.0 & 2.1 & B & $\mathrm{O}-\mathrm{F}-\mathrm{O}$ & 1.0 & 82 \\
\hline & & 4.5 & 2.0 & 2.2 & B & $\mathrm{O}-\mathrm{F}-\mathrm{O}$ & 0.5 & 65 \\
\hline & \multirow{6}{*}{0.13} & 4.2 & 2.0 & 2.1 & B & $\mathrm{O}-\mathrm{F}-\mathrm{O}$ & 0.5 & 59 \\
\hline & & 3.75 & 2.0 & 1.9 & $B$ & $\mathrm{O}-\mathrm{F}-\mathrm{O}$ & 1.0 & 78 \\
\hline & & 3.75 & 2.8 & 2.2 & SS & $\mathrm{O}-\mathrm{F}-\mathrm{O}$ & 1.0 & 81 \\
\hline & & 3.75 & 2.0 & 2.2 & $B$ & $\mathrm{~F}-\mathrm{O}-\mathrm{F}$ & 1.0 & 33 \\
\hline & & 3.75 & 2.0 & 2.4 & B & $\mathrm{O}-\mathrm{F}-\mathrm{O}$ & 1.0 & 81 \\
\hline & & 4.2 & 2.8 & 2.5 & SS & $\mathrm{O}-\mathrm{F}-\mathrm{O}$ & 0.5 & 68 \\
\hline 10.0 & 2.0 & 8.2 & 2.8 & 2.0 & SS & O-F-O & 1.1 & 46 \\
\hline
\end{tabular}

Based on the results from the experiments with hydrogen, the O-F-O configuration was used when the solid was fed through the burner to avoid melting the particles. Hydrogen is the main reductant at $1175{ }^{\circ} \mathrm{C}$ temperature, and CO contributes much less to the reduction especially in the presence of $\mathrm{CO}_{2}$. The hydrogen EDF values tested were 0.5 and 1 . This configuration yielded reduction degrees higher than with the F-O-F configuration, as shown in Figure 10.

The samples collected from these experiments showed no melting. 


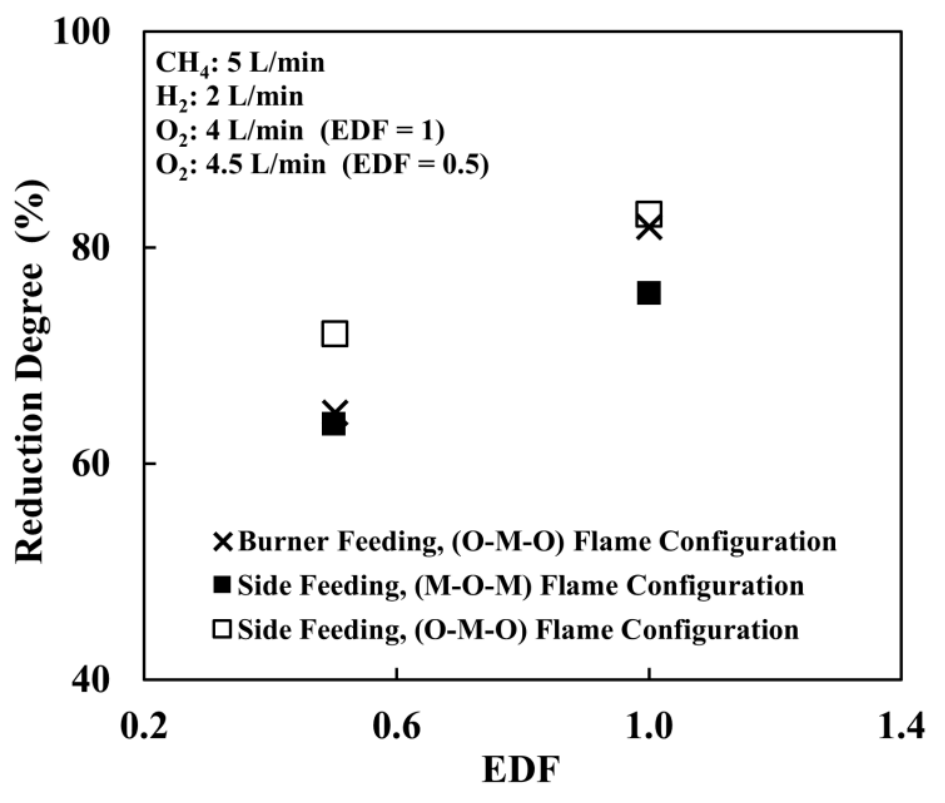

Figure $10 \%$ reduction vs. EDF on degree for different feeding positions and flame configurations. [Adapted from M. Elzohiery, Flash Reduction of Magnetite Concentrate Related to a Novel Flash Ironmaking Process, Ph.D. Dissertation, Salt Lake City, Utah: University of Utah, 2018.]

\subsection{Computational Fluid Dynamics (CFD) Simulation}

The laboratory flash reactor runs were simulated by a three-dimensional computational fluid dynamics (CFD) model. The governing equations for the gas phase in the Eulerian viewpoint and for the particles tracked in the Lagrangian framework using the stochastic trajectory model were solved using the commercial CFD software package ANSYS FLUENT $15.0[27,28]$.

\subsection{CFD Simulation Results for Hydrogen Reduction}

Figure 11 shows the shapes of the injection ports used in the CFD simulations. The calculated \% reduction and the associated experimental results are compared in Figure 12. There is a satisfactory agreement, except when the \% reduction was low. The ability to predict higher $\%$ reduction is more important in the design of industrial reactors, because the new technology should produce iron with a reduction degree greater than $90 \%$. Table 5 shows the test conditions, experimental and calculated degrees of reduction for the experiments selected for simulation from those listed in Table 3. 


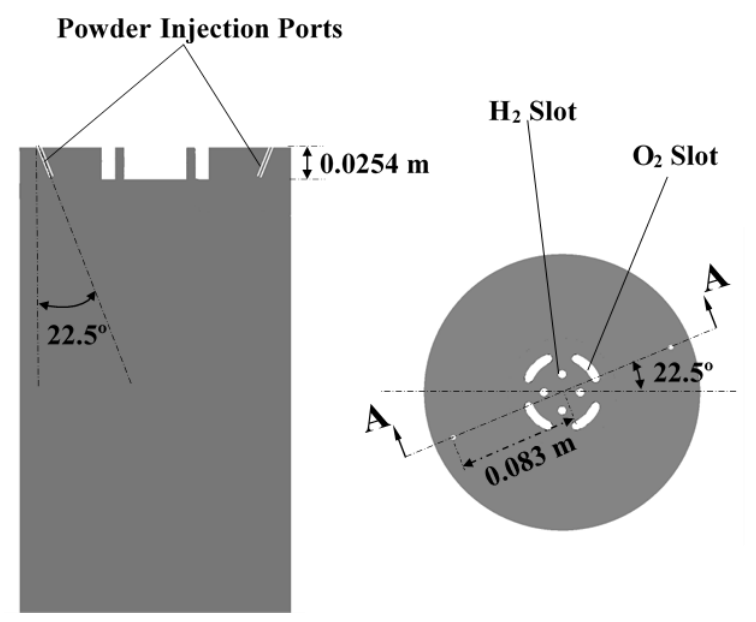

Figure 11 The configurations of injection positions: (Left) injection positions (A-A section); (Right) plan view. [Adapted from D.-Q. Fan, Computational Fluid Dynamics analysis and Design of Flash Ironmaking Reactors, Ph.D. Dissertation (Salt Lake City, Utah: University of Utah, 2019).]

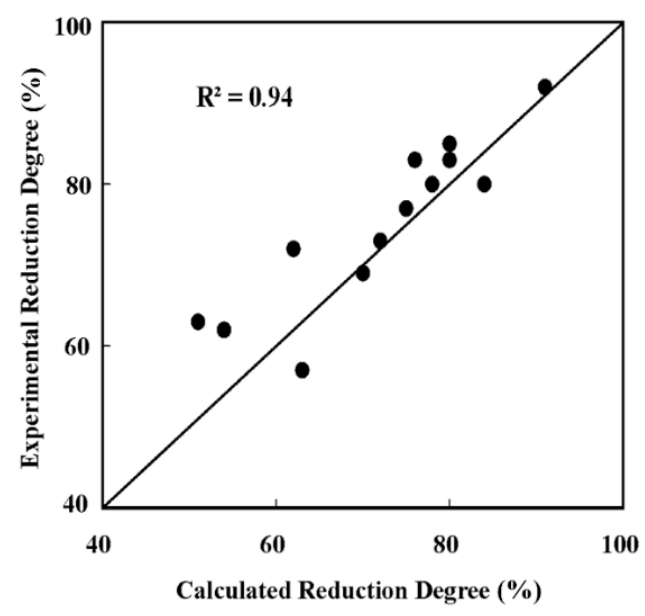

Figure 12 Experimental vs. simulated \% reduction. [Adapted from D.-Q. Fan, Computational Fluid Dynamics analysis and Design of Flash Ironmaking Reactors, Ph.D. Dissertation (Salt Lake City, Utah: University of Utah, 2019).]

Table 5 Experimental and CFD Run Conditions and Results (All solid feeding modes = SS; all $\mathrm{N} 2$ flow rates $=2.8 \mathrm{~L} / \mathrm{min} *$ ).

\begin{tabular}{|c|c|c|c|c|c|c|c|c|}
\hline $\begin{array}{l}\text { Flame } \\
\text { Config. }\end{array}$ & $\begin{array}{l}\mathrm{H}_{2} \text { Flow } \\
\text { Rate } \\
\text { (L/min)* }\end{array}$ & $\begin{array}{l}\mathrm{O}_{2} \quad \text { Flow } \\
\text { Rate } \\
\text { (L/min)* }\end{array}$ & $\begin{array}{l}\text { Conc. } \\
\text { Feed Rate } \\
\text { (g/min) }\end{array}$ & EDF & $\begin{array}{l}\text { CFD } \\
\text { Redn. } \\
\text { Degre } \\
\text { e (\%) }\end{array}$ & $\begin{array}{l}\text { Exp. } \\
\text { Redn. } \\
\text { Degre } \\
\text { e (\%) }\end{array}$ & $\begin{array}{l}\text { Max. } \\
\text { Flame } \\
\text { Temp. } \\
\text { (K) }\end{array}$ & $\begin{array}{l}\text { Avg. Res. } \\
\text { Time (s) }\end{array}$ \\
\hline $\mathrm{H}-\mathrm{O}-\mathrm{H}$ & 15.3 & 2.16 & 1.9 & 0.5 & 84 & 82 & 2722 & 5.4 \\
\hline $\mathrm{H}-\mathrm{O}-\mathrm{H}$ & & 2.72 & 2.1 & 0.06 & 63 & 57 & 2805 & 5.6 \\
\hline $\mathrm{H}-\mathrm{O}-\mathrm{H}$ & 20 & 2.96 & 1.8 & 0.5 & 80 & 84 & 2851 & 5 \\
\hline
\end{tabular}




\begin{tabular}{|c|c|c|c|c|c|c|c|c|}
\hline $\mathrm{H}-\mathrm{O}-\mathrm{H}$ & & 3.22 & 1.9 & 0.3 & 78 & 80 & 2879 & 5.1 \\
\hline $\mathrm{H}-\mathrm{O}-\mathrm{H}$ & & 3.70 & 2.0 & 0.1 & 51 & 63 & 2901 & 5.2 \\
\hline $\mathrm{H}-\mathrm{O}-\mathrm{H}$ & & 4.32 & 2.2 & 1.4 & 91 & 92 & 2966 & 3.6 \\
\hline $\mathrm{H}-\mathrm{O}-\mathrm{H}$ & 40 & 6.40 & 2.1 & 0.5 & 75 & 77 & 3017 & 3.7 \\
\hline $\mathrm{O}-\mathrm{H}-\mathrm{O}$ & & 6.40 & 2.3 & 0.5 & 80 & 87 & 2790 & 4.2 \\
\hline $\mathrm{H}-\mathrm{O}-\mathrm{H}$ & & 9.65 & 1.9 & 0.5 & 72 & 74 & 3030 & 2.9 \\
\hline $\mathrm{O}-\mathrm{H}-\mathrm{O}$ & & 9.65 & 2.1 & 0.5 & 76 & 83 & 2898 & 3.3 \\
\hline $\mathrm{H}-\mathrm{O}-\mathrm{H}$ & 60 & 10.1 & 1.67 & 0.3 & 70 & 69 & 3034 & 2.9 \\
\hline $\mathrm{H}-\mathrm{O}-\mathrm{H}$ & & 10.65 & 2.3 & 0.3 & 62 & 72 & 3041 & 2.9 \\
\hline $\mathrm{H}-\mathrm{O}-\mathrm{H}$ & & 11.2 & 2.0 & 0.2 & 54 & 65 & 3047 & 3 \\
\hline
\end{tabular}

*Flow rates are at $298 \mathrm{~K}\left(25^{\circ} \mathrm{C}\right)$ and $0.85 \mathrm{~atm}$ at Salt Lake City $(1 \mathrm{~atm}=101.3 \mathrm{kPa})$

The same CFD program used for hydrogen reduction in the Utah Flash Reactor was also used to simulate the experiments with methane-oxygen feed, as reported elsewhere [27].

\section{Operation of a Pilot-Plant Scale Flash Reactor}

Here, we will describe a Pilot Flash Reactor operated at $1200-1550{ }^{\circ} \mathrm{C}$ with a solid feed rate of 1 $-7 \mathrm{~kg} / \mathrm{h}$, shown in Figure 13 [28] together with its operation and the operational difficulties. In this larger-scale reactor, natural gas was used as the fuel/reducing gas instead of methane, as would be in an industrial flash ironmaking process.

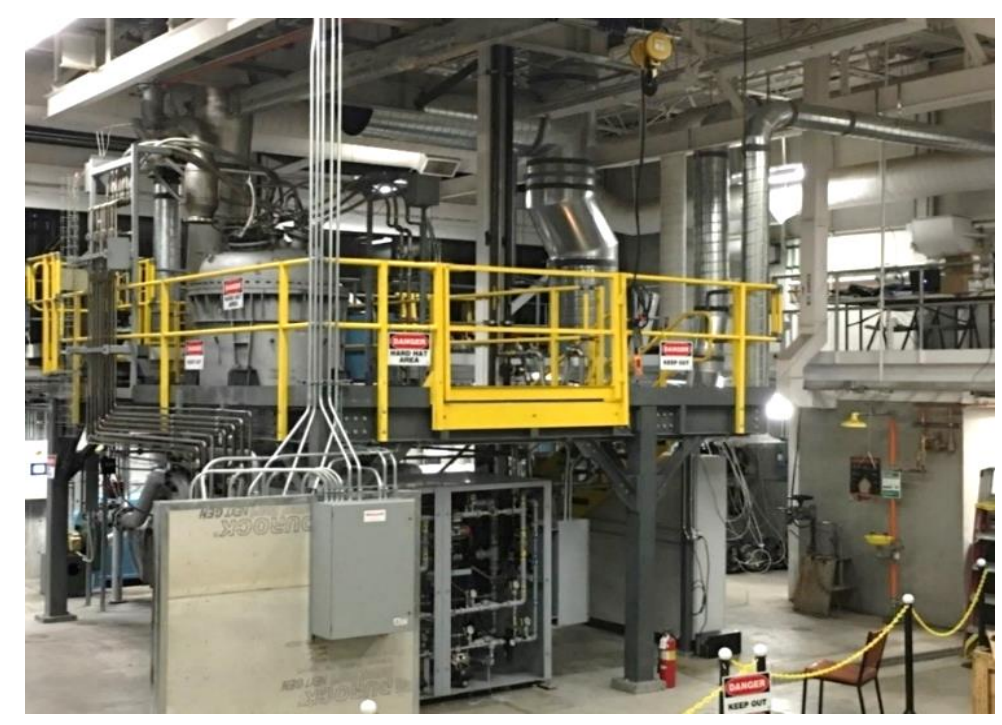

Figure 13 The pilot plant with a flash reactor installed at the University of Utah. [Adapted from M. Elzohiery, Flash Reduction of Magnetite Concentrate Related to a Novel Flash Ironmaking Process, Ph.D. Dissertation, Salt Lake City, Utah: University of Utah, 2018.] 


\subsection{Facility}

The Pilot Flash Reactor consisted of a reactor vessel, burners, a quench tank for product collection, a stack, a powder feeding system, and human-machine interface. Figure 14 shows a sketch of the main parts of the reactor vessel.

Reactor Body and Roof: The carbon steel vessel was lined with $0.3 \mathrm{~cm}$ of high quality aluminasilica fiber blanket, $8 \mathrm{~cm}$ of insulating layer of high fired, lightweight crystalline silica, and $18 \mathrm{~cm}$ of castable $99.8 \%$ alumina refractory layer. The outer shell temperature was about $220{ }^{\circ} \mathrm{C}$ when the temperature of the inside alumina surface was $1450{ }^{\circ} \mathrm{C}$. The inner diameter of the vessel was $80 \mathrm{~cm}$ and the height $200 \mathrm{~cm}$, as shown in Figure 15.

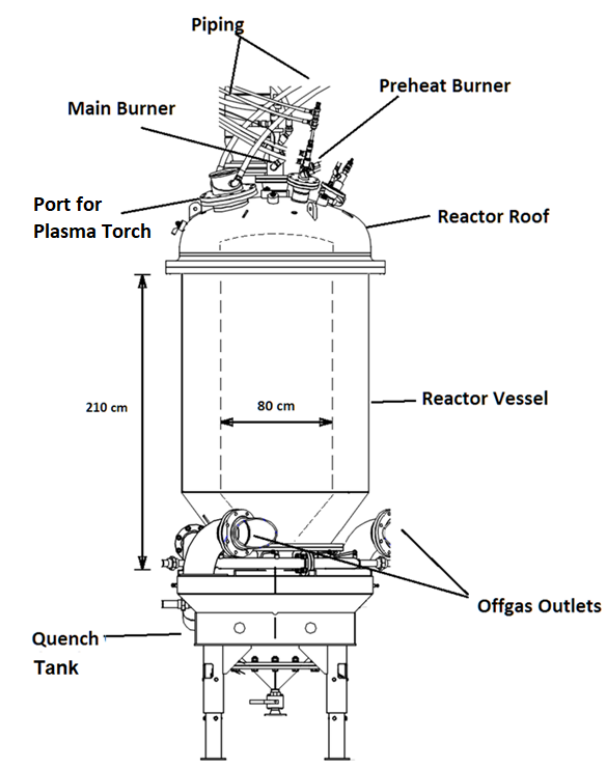

Figure 14 Sketch of the Pilot Flash Reactor. [Adapted from M. Elzohiery, Flash Reduction of Magnetite Concentrate Related to a Novel Flash Ironmaking Process, Ph.D. Dissertation, Salt Lake City, Utah: University of Utah, 2018.]

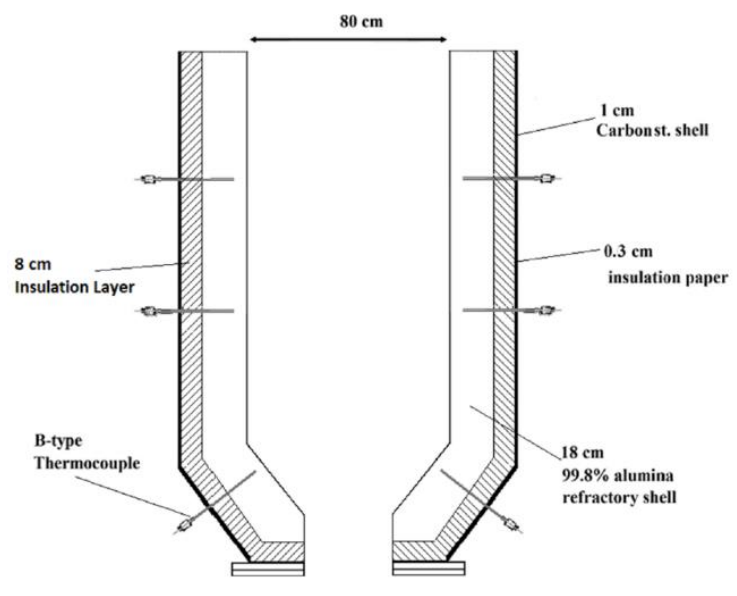

Figure 15 Sketch of the reactor body showing the wall layers. [Adapted from M. Elzohiery, Flash Reduction of Magnetite Concentrate Related to a Novel Flash Ironmaking Process, Ph.D. Dissertation, Salt Lake City, Utah: University of Utah, 2018.] 
The roof had an opening for burners as well as an emergency off-gas conduit equipped with a rupture disk, which was designed to break when the pressure inside the reactor exceeded 1.5 atm above the external pressure.

B-type thermocouples were inserted such that the junctions protruded $2.5 \mathrm{~cm}$ into the reactor from the inside surface of the wall. These thermocouples were capable of measuring temperatures up to $1860^{\circ} \mathrm{C}$. The thermocouple signals were used to control the temperature inside the reactor vessel.

Burners: The Pilot Flash Reactor had a burner for preheating the reactor and a separate burner for the process gases. Figure 16 shows a sketch for the cross section of the preheat and the main burner.
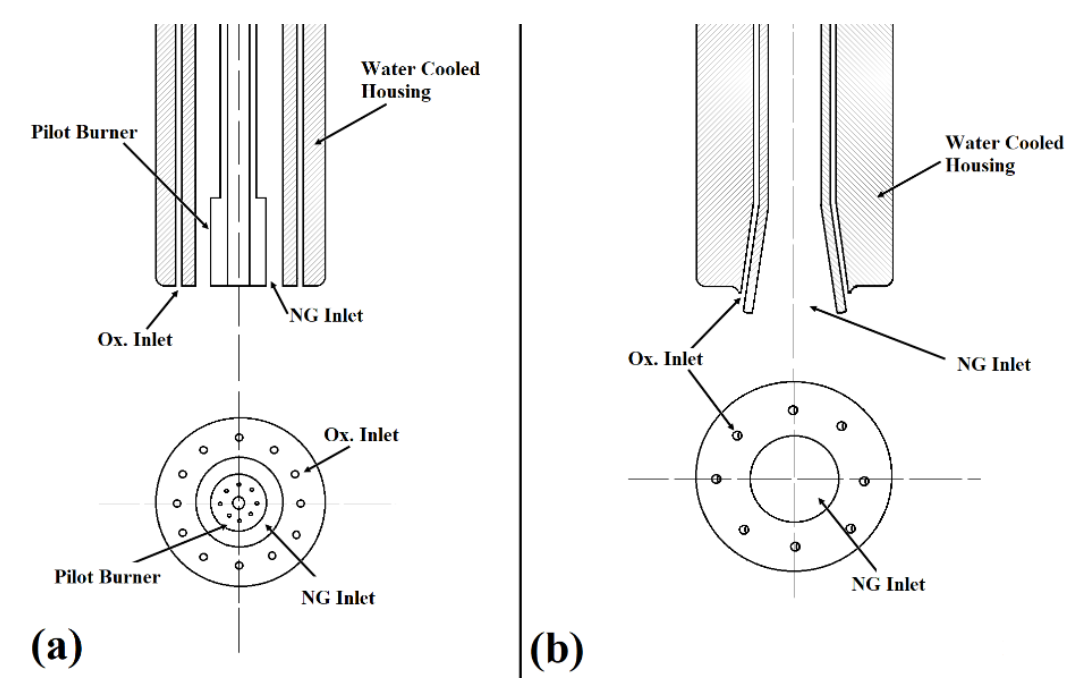

(b)

Figure 16 Sketches for (a) Preheat burner and (b) Main burner. [Adapted from M. Elzohiery, Flash Reduction of Magnetite Concentrate Related to a Novel Flash Ironmaking Process, Ph.D. Dissertation, Salt Lake City, Utah: University of Utah, 2018.]

The preheat burner used a natural gas-oxygen flame. The main burner fed natural gas and industrial oxygen to produce a high-temperature reducing gas mixture. The maximum flow rates that the main burner could operate at were 954 SLPM of oxygen and 1116 SLPM of natural gas. The standard conditions were pre-defined in the instruments as $1 \mathrm{~atm}$ and $25^{\circ} \mathrm{C}$. The burner nozzle was made of Inconel alloy and a zirconia refractory block surrounded the burner tip. This burner was designed to have a flame configuration of O-F-O, as determined from the results of the laboratory flash reactor.

Off-gas Analyzer: The composition of the off-gas was analyzed before it flowed into the flare stack, using a NOVA gas analyzer Model 875A Steel Making Analyzer supplied by Tenova, ON, Canada. An NDIR (infrared) detector was used to measure the contents of $\mathrm{CO}, \mathrm{CO}_{2}$ and $\mathrm{CH}_{4}$, a thermal conductivity cell measured the $\mathrm{H}_{2}$ content, and an electrochemical sensor measured the $\mathrm{O}_{2}$ content. This gas analyzer had a resolution of $\pm 0.1 \%$. The gas analyzer was calibrated before each run with a calibration gas mixture that contained a fixed composition of $\mathrm{H}_{2}, \mathrm{CO}, \mathrm{CO}_{2}$ and $\mathrm{CH}_{4}$.

Concentrate Feeding System: An HA5171P-D pneumatic powder feeder supplied by HAI, Placentia, CA, U.S. fed the concentrate into the reactor at a rate of $1-7 \mathrm{~kg} / \mathrm{h}$. Nitrogen gas at a flow rate of 11 SLPM was used as the carrier gas. The powder feeder had weighing cells that recorded the average feeding rate during the operation. 
Gas Leak Detectors: Industrial gas leak detectors supplied by Honeywell, Lincolnshire, IL, U.S. were placed in different places around the reactor and inside the building to monitor any $\mathrm{H}_{2}, \mathrm{CO}$, and $\mathrm{CH}_{4}$ gas leak. All the detectors were connected to the main PLC to shut down all the gas flows in the case of a major leak that required evacuation of the building and purging of the vessel.

Human Machine Interface: The Human Machine Interface (HMI) consisted of the main PLC and a PC. The operator monitored all parts of the facility and ran the reactor through the computer to which the main PLC continuously fed information. All the safety and emergency procedures relied on the PLC. The main PLC was supplied by ACS Company, Boise, ID, U.S. A screen shot of the computer monitor that displayed and controlled all the parameters of the operation is shown in Figure 17.

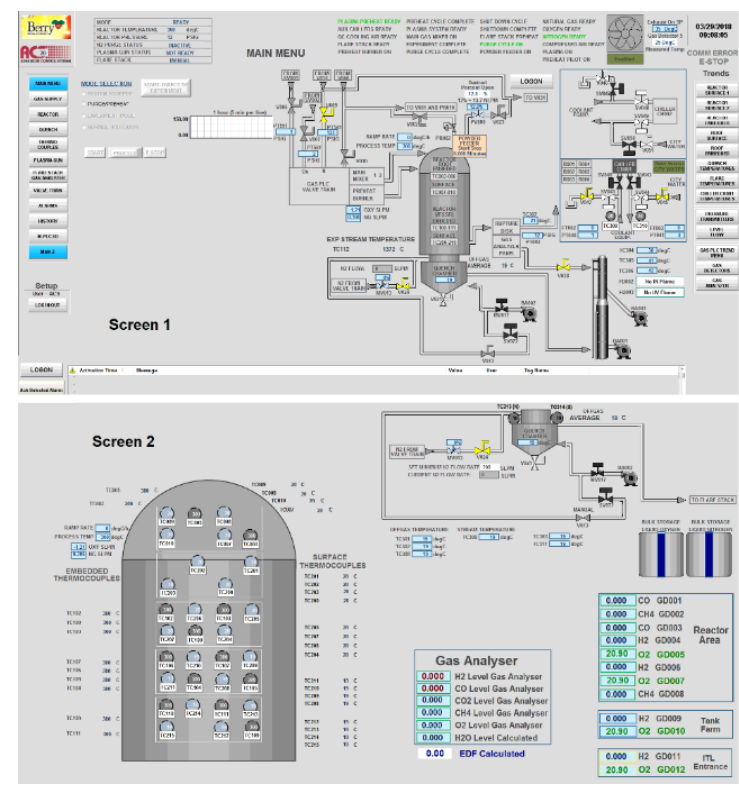

Figure 17 Control screen for the HMI. [Adapted from M. Elzohiery, Flash Reduction of Magnetite Concentrate Related to a Novel Flash Ironmaking Process, Ph.D. Dissertation, Salt Lake City, Utah: University of Utah, 2018.]

Other Details of Pilot Plant: Other details of the operation of the Pilot Reactor are described elsewhere [28].

\subsection{Operation of the Pilot Flash Reactor}

The solid fed to this reactor was as-received magnetite concentrate with a particle size range of $<90 \mu \mathrm{m}$ by sieving the concentrate with a $90 \mu \mathrm{m}$ sieve and using the concentrate that has passed through it. For the experiment that was performed with particle size range $32-90 \mu \mathrm{m}$, the concentrate was sieved and collected between 90 and $32 \mu \mathrm{m}$ sieves. All the components of the reactor were installed and a leak test was performed by capping the off-gas pipes and pressurizing the vessel to $2.0 \mathrm{~atm}$ for 45 minutes to make sure that there were no leaks from any components. The system was preheated to the target temperature at a rate of $90-95^{\circ} \mathrm{C} / \mathrm{h}$, which was the highest heating rate that could be applied to avoid cracking the refractories. The heating cycle was automatically controlled by the $\mathrm{HMI}$, and the flow rates of natural gas and oxygen were varied based on the measured temperature of the reactor vessel. 
Once the system reached the target temperature, the oxygen and natural gas were switched to the main burner. However, the pilot burner was kept ignited all the time with small flows of the fuel and oxygen. The system then sent a signal to the flare stack to turn on a pilot flame and burn the off-gas. Once the system received a signal that the flare stack was operating, the operator changed the flow rates of the oxygen and natural gas through the main burner to the target experimental values.

The off-gas composition was measured during the run and the hydrogen reducing power was calculated on the HMI. The flow rates of oxygen and natural gas were adjusted to achieve the target reducing power. After feeding a predetermined quantity of the concentrate, the system was shut down by switching all the gas streams to nitrogen. The flare stack was kept running for 5 minutes longer to burn any residual combustible gases flowing out of the reactor. The reactor was left to cool to a temperature below $400{ }^{\circ} \mathrm{C}$ in the main vessel and $25^{\circ} \mathrm{C}$ in the quench tank. This typically took 4 days. The collected sample was analyzed by ICP to determine its reduction degree.

\subsection{Results from Pilot Flash Reactor Runs}

Table 6 shows the results from the Pilot Flash Reactor runs. These results were used to develop a CFD model that would be used to optimize the operating conditions and reactor sizes to be used in an industrial reactor [30].

Table 6 The results of the Pilot Flash Reactor runs.

\begin{tabular}{|c|c|c|c|c|c|c|}
\hline $\begin{array}{l}\text { Inner Wall } \\
\text { Temperature } \\
\left({ }^{\circ} \mathrm{C}\right)\end{array}$ & $\begin{array}{l}\text { Magnetite } \\
\text { Concentrate } \\
\text { Feeding } \\
\text { Rate } \\
(\mathrm{kg} / \mathrm{h})\end{array}$ & $\begin{array}{l}\text { Gas Flor } \\
\text { Main Bu } \\
\text { NG } \\
\text { (SLPM) }\end{array}$ & te (SLPM)* & $\mathrm{H}_{2}$ EDF & $\begin{array}{l}\text { Nominal } \\
\text { Residence } \\
\text { Time (s) }\end{array}$ & $\begin{array}{l}\text { RD } \\
\text { (\%) }\end{array}$ \\
\hline $1200-1130$ & 5.0 & 404 & 321 & 0.76 & 12.5 & 65 \\
\hline $1290-1220$ & 1.8 & 410 & 293 & 0.84 & 12.0 & 79 \\
\hline $1290-1210$ & 2.9 & 410 & 293 & 0.96 & 12.0 & 82 \\
\hline $1290-1230$ & 2.5 & 358 & 270 & 1.00 & 13.3 & 83 \\
\hline $1290-1240$ & 3.5 & 512 & 327 & 1.07 & 10.2 & 76 \\
\hline $1330-1230$ & 4.7 & 330 & 200 & 1.36 & 15.3 & 89 \\
\hline $1330-1230$ & 4.5 & 330 & 200 & 1.44 & 15.3 & 87 \\
\hline $1330-1230$ & 5.2 & 500 & 290 & 3.00 & 10.6 & 80 \\
\hline $1330-1230$ & 4.3 & 500 & 290 & 3.00 & 10.6 & 82 \\
\hline $1355-1260$ & 5.5 & 235 & 190 & 0.03 & 18.3 & 7 \\
\hline $1350-1300$ & 4.0 & 255 & 209 & 0.15 & 17.0 & 49 \\
\hline $1350-1270$ & 4.5 & 275 & 212 & 0.20 & 16.2 & 31 \\
\hline $1340-1280$ & 5.0 & 280 & 209 & 0.21 & 16.2 & 37 \\
\hline $1350-1290$ & 4.6 & 280 & 230 & 0.50 & 15.6 & 80 \\
\hline
\end{tabular}




\begin{tabular}{lllllll}
\hline $1400-1300$ & 6.3 & 300 & 240 & 0.82 & 14.4 & 88 \\
$1400-1300$ & 5.0 & 330 & 200 & 1.51 & 14.6 & 100 \\
$1415-1350$ & 4.5 & 220 & 191 & 0.07 & 18.0 & 18 \\
$1410-1360$ & 4.0 & 240 & 195 & 0.33 & 17.1 & 32 \\
$1410-1330$ & 5.0 & 295 & 221 & 0.50 & 14.7 & 66 \\
$1410-1330$ & 6.0 & 300 & 210 & 0.70 & 14.9 & 74 \\
$1410-1320$ & 5.0 & 300 & 210 & 0.82 & 14.9 & 82 \\
\hline
\end{tabular}

* The flow rates of $\mathrm{NG}$ and $\mathrm{O}_{2}$ in the pilot burner, as opposed to those of the main burner listed in the table, were 9.6 and 37.6 SLPM, respectively. The flow rate of $\mathrm{N}_{2}$ in the powder feeder was 10.7 SLPM.

Different experimental runs were designed and made in this reactor to yield a range of reduction degrees, deliberately at less than complete reduction, to better examine the effects of the operating conditions and validate the CFD model.

In this reactor, no soot was formed during the experiments. LECO analysis was performed on some of the samples collected from this work. Only one sample contained a small amount of carbon, less than $0.24 \% \mathrm{C}$, while all other samples contained no detectable amount of carbon.

The experiments in the pilot plant were performed at different temperatures and reducing powers of the gas with the aim of obtaining enough data for designing the industrial flash reactor. A nominal residence time for the particles was calculated, for a general reference, based on the total volumetric flow rate of the gases at the experimental temperature and the total volume of the reactor vessel which was $1.01 \mathrm{~m}^{3}$. When the velocities of the gases and the particles at the injection points are rigorously applied, the actual residence time would be shorter. More accurate residence time distribution was obtained by the CFD simulation of the operation.

The results showed good reproducibility within $\pm 5 \%$ of the average reduction degree by repeating the same experiment at least 3 times. This represents a very high degree of reproducibility, considering the complexity of the operation and design of this large unit.

\subsection{CFD Simulation of the Pilot Reactor Operation}

The same CFD model for the laboratory flash reactor discussed above was used for the pilot reactor runs [30]. 480 particle streams were released from the particle injection ports. During a run the wall temperature somewhat varied with time, Since our model was a steady-state model, the wall boundary condition was represented by an average tempeature that gives a rate constant which represents the average rate constant over the period of change, computed using a separate MATLAB program. This averaging method was thought to be somewhat better than the arithmetic average of the varying temperature. These inner wall temperatures used in the simulation are shown in Table 7.

The particle size distribution of the concentrate measured by the supplier was $<90 \mu \mathrm{m}$ and the concentrate was used as-received in Runs 2, 3, 5, and 6. For Runs 1 and 4, the concentrate was screened to $32-90 \mu \mathrm{m}$. The rates of a particle assemblage can be represented by that of the uniform particles of the mass average size $[31,32]$ and the particles in this size range move with a negligible slip velocity in the flash reactor [21]. Considering these factors, the CFD simulation used the mass 
average particle sizes listed in Table 7, which simplified the computation greatly, without much loss of accuracy of the computed results.

Table 7 Run conditions for the pilot reactor and CFD simulation results.

\begin{tabular}{|c|c|c|c|c|c|c|c|c|c|}
\hline $\begin{array}{l}\text { Ru } \\
\text { n \# }\end{array}$ & $\begin{array}{l}\text { Inner } \\
\text { Tempera } \\
\left({ }^{\circ} \mathrm{C}\right) \\
\text { Averag } \\
\text { e used } \\
\text { for } \\
\text { Simulat } \\
\text { ion }\end{array}$ & $\begin{array}{l}\text { Range } \\
\text { during } \\
\text { Run }\end{array}$ & $\begin{array}{l}\text { Magneti } \\
\text { te } \\
\text { Concent } \\
\text { rate } \\
\text { Feeding } \\
\text { Rate } \\
\text { (kg/h) }\end{array}$ & $\begin{array}{l}\text { Main } \\
\text { Gas } \\
\text { Rate } \\
\text { (SLPN }\end{array}$ & $\begin{array}{l}\text { urner } \\
\text { Flow } \\
\text { a) }\end{array}$ & $\begin{array}{l}\text { Particle } \\
\text { size } \\
(\mu \mathrm{m}) \\
\text { (Mass } \\
\text { average } \\
\text { used for } \\
\text { simulatio } \\
\mathrm{n})\end{array}$ & $\begin{array}{l}\mathrm{O}_{2} \text { to } \\
\text { Natura } \\
\mathrm{I} \text { Gas } \\
\text { molar } \\
\text { ratio }\end{array}$ & $\begin{array}{l}\text { Experim } \\
\text { ental RD } \\
\text { (\%) ( } \pm 5 \\
\%)\end{array}$ & $\begin{array}{l}\text { CFD } \\
\text { Simulat } \\
\text { ion RD } \\
(\%)\end{array}$ \\
\hline 1 & 1253 & $\begin{array}{l}1483- \\
1563\end{array}$ & 2.5 & 419 & 331 & 45 & 0.79 & 94 & 99.8 \\
\hline 2 & 1275 & $\begin{array}{l}1483- \\
1563\end{array}$ & 4.3 & 509 & 328 & 32 & 0.64 & 80 & 84.5 \\
\hline 3 & 1353 & $\begin{array}{l}1483- \\
1563\end{array}$ & 5 & 339 & 238 & 32 & 0.7 & 94.5 & 99.6 \\
\hline 4 & 1167 & $\begin{array}{l}1483- \\
1563\end{array}$ & 5 & 413 & 359 & 45 & 0.87 & 74 & 99.8 \\
\hline 5 & 1321 & $\begin{array}{l}1483- \\
1563\end{array}$ & 4.6 & 289 & 273 & 32 & 0.94 & 72.5 & 99.5 \\
\hline 6 & 1326 & $\begin{array}{l}1483- \\
1563\end{array}$ & 4 & 264 & 247 & 32 & 0.93 & 50 & 85 \\
\hline
\end{tabular}

Oxygen and natural gas input temperature was $25^{\circ} \mathrm{C}$.

(a) Flow rates are calculated at $25^{\circ} \mathrm{C}$ and $0.85 \mathrm{~atm}$, the barometric pressure at Salt Lake City.

(b)Temperatures of inner wall were recorded during the main experiment.

The CFD model predicted the $\mathrm{H}_{2}$ and $\mathrm{CO}$ concentrations within 93\% accuracy for most runs, as shown in Figure 18. The experimental values of \% reduction are compared with the CFD results in Table 7. The reduction degrees agree well for the first three runs. The agreement is not as good for the last three runs. The reason for this is likely to be because of the neglect of particle interactions for Runs 4 - 6. The temperature of the particle-gas stream in the main reaction zone was largely uniform, and this value is used to represent the reactor temperature. These runs had higher ratios of oxygen to natural gas and thus higher temperatures than the other runs, above $1577^{\circ} \mathrm{C}$, which is higher than the melting point of iron at $1538^{\circ} \mathrm{C}$. Particle agglomerate together more readily at these high temperatures, as shown previously during flash smelting of copper [33-35]. This might have caused lower reduction rates in the actual cases than in the simulation. This points to the need for improving the CFD model to account for particle coalescence at high temperatures. 

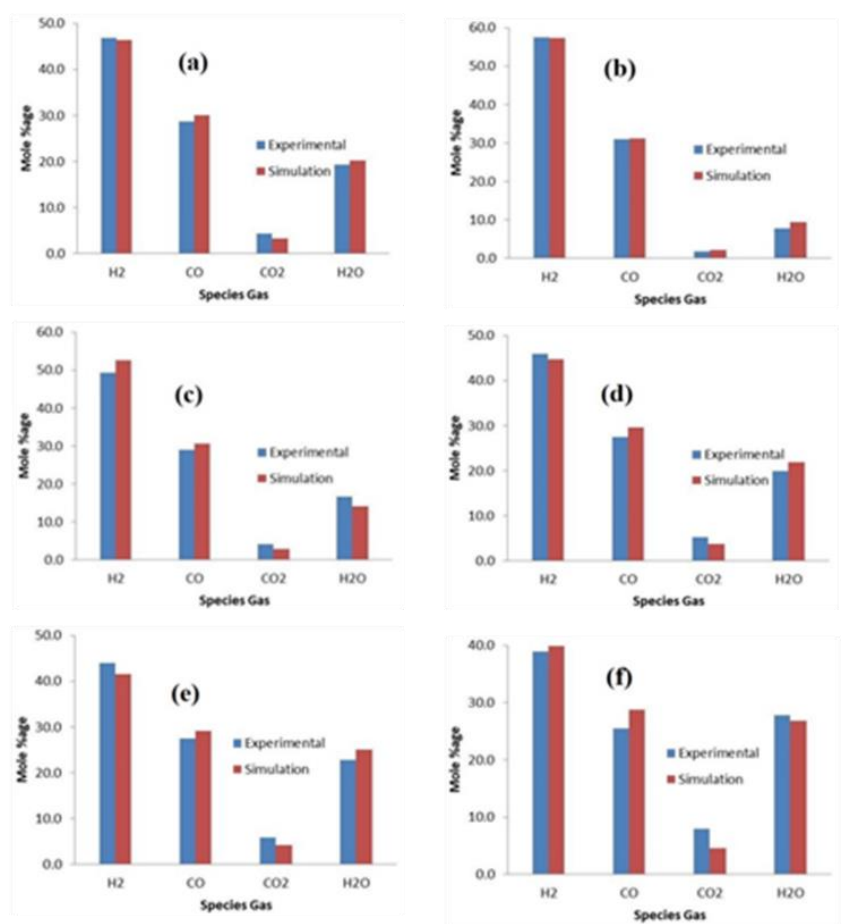

Figure 18 Comparison of the measured off-gas contents of $\mathrm{H}_{2}, \mathrm{CO}, \mathrm{CO}_{2}$, and $\mathrm{H}_{2} \mathrm{O}$ with the computed values: (a) Run 1, (b) Run 2,(c) Run 3, (d) Run 4, (e) Run 5, and (f) Run 6.

The temperature of the particle-gas strean in Run 1 was also above $1577^{\circ} \mathrm{C}$, but the solid feed rate in this run was only about one-half of the values in Runs $4-6$. The lower solid feed rate in Run 1 together with the fact that portions of the particles usually get stuck on the wall significantly lowered the possibility of particles in the gas stream to agglomerate in Run 1 . The scanning electron microscope (SEM) micrographs of the samples from Runs 1 - 3 in Figure 19 indicate that particle did not fuse in these runs, yielding the satisfactory agreements between the experimental and CFD results. The micrographs of the sample collected from Run 4 shown in Figure 19 indicates a larger amount of big particles, pointing to greater extent of particle agglomeration.

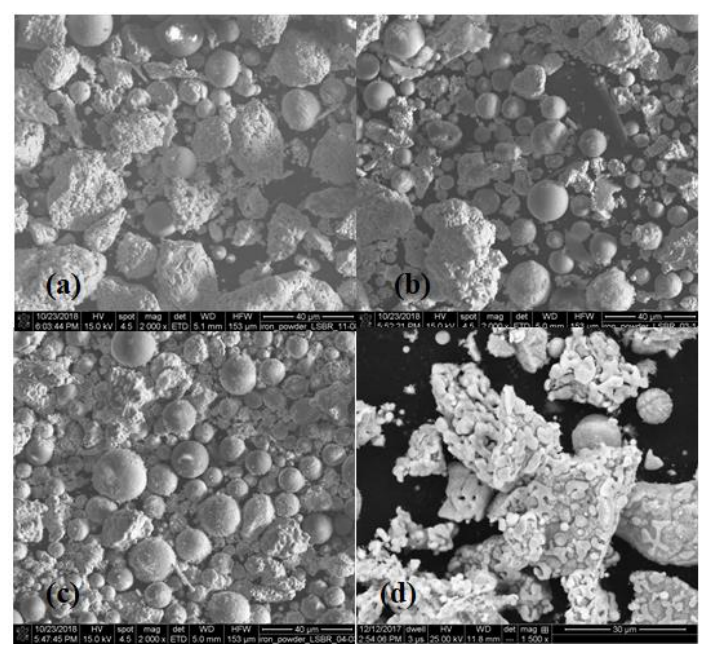

Figure 19 SEM micrographs of samples from (a) Run 1, (b) Run 2, (c) Run 3, and (d) Run 4. [Adapted from A. Abdelghany, D.-Q. Fan, and H. Y. Sohn, Metall. Mater. Trans. B, 51, 2046-2056 (2020).] 


\section{Process and Economic Analysis}

Based on the potential advantages pf the new technology and the results of the process feasibility studies, process and economic analyses have been performed [12-15]. The results of these analyses indicated that the new ironmaking technology will consume up to $44 \%$ less energy than the blast furnace when the former is run in the reformerless mode, i.e. direct partial combustion in the reactor, and it will emit up to $51 \%$ less carbon dioxide. When hydrogen is used, the proposed process would consume up to $60 \%$ less energy with little $\mathrm{CO}_{2}$ emissions. However, it is noted that a more accurate comparison must include the energy consumption and $\mathrm{CO}_{2}$ emissions for the production of natural gas, hydrogen or coal.

An economic feasibility analysis [15] indicated that the new technology using natural gas with insitu partial combustion would be economical at this time, owing to the small capital and operating costs as well as the low price of natural gas. The sensitivity analysis performed on the estimated NPV indicated that the price of natural gas affects the NPV most strongly. These economic analyses point to the fact that the proposed ironmaking technology would be economically feasible at this time if it is operated using natural gas.

\subsection{Summary}

The overall process of developing a novel Flash Ironmaking Technology (FIT) have been described in this article.

Rate equations for the reduction of iron ore concentrate by hydrogen, carbon monoxide, and a mixture of the two formulated in this work established the fundamental feasibility of the concept of the flash ironmaking and form the basis of the design of a reactor to realize the process. Scale-up experiments were performed in a laboratory flash reactor that operated at conditions similar to those of the industrial flash ironmaking reactor, and $>90 \%$ reduction degree was obtained at temperature as low as $1175^{\circ} \mathrm{C}$.

A pilot reactor that operated in the temperature range $1200-1550^{\circ} \mathrm{C}$ was installed and operated to collect the data necessary for scaling up the process to an industrial scale. This reactor was used to validate the design concept of the Flash Ironmaking in terms of heat supply, residence time, reduction degree, and the determination of optimum operating conditions. These tests also identified a number of technical hurdles. Full reduction of the magnetite concentrate was achieved at $1350{ }^{\circ} \mathrm{C}$ and $\mathrm{H}_{2}$ EDF $=1.5$ in the pilot reactor. This investigation proved the technical feasibility of the flash ironmaking technology for large-scale iron production. The results of this work will facilitate the complete design for the industrial flash ironmaking reactor.

The new technology does not require pellets, sinters and coke. Instead, it would produce iron directly from concentrates using natural gas or hydrogen. As a result, the energy consumption is expected to be up to $44 \%$ less than that for the average blast furnace process when the Flash Ironmaking Technology (FIT) is operated with natural gas in the reformerless mode, i.e. in situ partial combustion, and it will emit up to $51 \%$ less carbon dioxide. When hydrogen is used, the proposed process would consume up to $60 \%$ less energy with little carbon dioxide emissions.

It is hoped that the planning of the overall development of the flash ironmaking technology, the experiences obtained from the testing steps, and results from them would be a significant source of information for future researchers and engineers who may either work on this technology or develop similar or related other technologies. 


\section{Acknowledgments}

The authors wish to thank all other graduate and undergraduate students and postdoctoral associates who over the years participated in various aspects in the development of the Flash Ironmaking Technology described in this article. We acknowledge the support and resources from the Center for High Performance Computing at the University of Utah. The financial support from the U.S. Department of Energy under Award Number DE-EE0005751, with cost share by the American Iron and Steel Institute (AISI) and the University of Utah, is gratefully acknowledged.

\section{Author Contributions}

Hong Yong Sohn directed the overall research program and wrote the manuscript of this overview article. Mohamed Elzohiery was the lead assistant for the various experimental programs, including data analysis, performed in the development project and reviewed the manuscript. DeQiu Fan was responsible for the development of the CFD simulation program for the overall project, participated together with other assistants in the running of the pilot plant facility, and reviewed the manuscript.

\section{Competing Interests}

Disclaimer: This report was prepared as an account of work sponsored by an agency of the United States Government. Neither the United States Government nor any agency thereof, nor any of their employees, makes any warranty, express or implied, or assumes any legal liability or responsibility for the accuracy, completeness, or usefulness of any information, apparatus, product, or process disclosed, or represents that its use would not infringe privately owned rights. Reference herein to any specific commercial product, process, or service by trade name, trademark, manufacturer, or otherwise does not necessarily constitute or imply its endorsement, recommendation, or favoring by the United States Government or any agency thereof. The views and opinions of authors expressed herein do not necessarily state or reflect those of the United States Government or any agency thereof.

On behalf of all authors, the corresponding author states that there is no conflict of interest.

\section{References}

1. Sohn HY. Suspension ironmaking technology with greatly reduced energy requirement and $\mathrm{CO}_{2}$ emissions. Steel Times Int. 2007; 31: 68-72.

2. Tacke KH, Steffen R. Hydrogen for the reduction of iron ores - State of the art and future aspects. Stahl und Eisen. 2004; 124: 45-52.

3. Steel statistical yearbook 2007 [Internet]. International Iron and Steel Institute; 2007. Available from: $\quad$ https://www.worldsteel.org/en/dam/icr:5a3cd3bc-79f9-44e5-ac54ed231832cb21/Steel\%2Bstatistical+yearbook+2007.pdf.

4. Lockwood G. Ironmaking process alternatives screening study, Volume 1. U.S.: Department of Energy, Office of Scientific and Technical Information; 2000; No. 010529.01.

5. Brent AD, Mayfield PL, Honeyands TA. The Port Hedland FINMET ${ }^{\circledR}$ Project - Fluid bed production of high quality virgin iron for the 21 st century. In: ICARISM '99: Proceedings of the International Conference on Alternative Routes of Iron and Steelmaking: 15-17 September 1997, Perth, W.A 
(Publications series). 1st ed. Australia: Australasian Institute of Mining and Metallurgy; 1999. p. 111.

6. Husain R, Sneyd S, Weber P. Circored and Circofer two new fine ore reduction processes. In: ICARISM '99: Proceedings of the International Conference on Alternative Routes of Iron and Steelmaking: 15-17 September 1997, Perth, W.A (Publications series). 1st ed. Australia: Australasian Institute of Mining and Metallurgy; 1999. p. 123.

7. Macauley D. Options increase for non-BF ironmaking. Steel Times Int. 1997; 21: 20-22.

8. Sohn HY, Choi ME, Zhang Y, Ramos JE. Suspension reduction technology for ironmaking with low $\mathrm{CO}_{2}$ emission and energy requirement. Iron Steel Technol. 2009; 6: 158-165.

9. Sohn HY, Choi ME, Zhang Y, Ramos JE. Suspension ironmaking technology with greatly reduced $\mathrm{CO}_{2}$ emission and energy requirement. In: Energy Technology Perspectives: Carbon Dioxide Reduction and Production from Alternative Sources. Warrendale, PA: TMS (The Minerals, Metals \& Materials Society); 2009. p. 93-101.

10. Sohn HY, Choi ME. Development of a novel gas-suspension ironmaking technology with greatly reduced energy consumption and $\mathrm{CO}_{2}$ emissions. In: TMS 2010 139th Annual Meeting and Exhibition - Supplemental Proceedings, Volume 1 - Materials Processing and Properties. Warrendale, PA: TMS (The Minerals, Metals \& Materials Society); 2010. p. 347-354.

11. USGS. 2005 Minerals yearbook - Iron ore. Reston, Virginia: U.S. Geological Survey; 2007.

12. Pinegar HK, Moats MS, Sohn HY. Process simulation and economic feasibility analysis for a hydrogen-based novel suspension ironmaking technology. Steel Res Int. 2011; 82: 951-963.

13. Pinegar HK, Moats MS, Sohn HY. Flowsheet development, process simulation and economic feasibility analysis for novel suspension ironmaking technology based on natural gas: Part 1 Flowsheet and simulation for ironmaking with reformerless natural gas. Ironmak Steelmak. 2012; 39: 398-408.

14. Pinegar HK, Moats MS, Sohn HY. Flowsheet development, process simulation and economic feasibility analysis for novel suspension ironmaking technology based on natural gas: Part 2 Flowsheet and simulation for ironmaking combined with steam methane reforming. Ironmak Steelmak. 2013; 40: 32-43.

15. Pinegar HK, Moats MS, Sohn HY. Flowsheet development, process simulation and economic feasibility analysis for novel suspension ironmaking technology based on natural gas: Part 3 Economic feasibility analysis. Ironmak Steelmak. 2013; 40: 44-49.

16. Annual Energy Outlook [Internet]. Washington, DC: U.S. Energy Information Administration; 2011. Available from: http://www.eia.gov/forecasts/aeo/index.cfm

17. Hydrogen posture plan - an integrated research, development and demonstration plan [Internet]. U.S. Department of Energy, U.S. Department of Transportation; 2006. Available from: https://www.hydrogen.energy.gov/pdfs/hydrogen posture plan dec06.pdf.

18. Züttel A, Borgschulte A, Schlapbach L. Hydrogen as a future energy carrier. Weinheim, Germany: WILEY-VCH; 2008.

19. Fan DQ, Mohassab $Y$, Elzohiery $M$, Sohn HY. Analysis of the hydrogen reduction rate of magnetite concentrate particles in a drop tube reactor through CFD modelling. Metall Mater Trans B. 2016; 47: 1669-1680.

20. Fan DQ, Elzohiery M, Mohassab Y, Sohn HY. Rate-enhancement effect of CO in magnetite concentrate particle reduction by $\mathrm{H}_{2}+\mathrm{CO}$ mixtures. Ironmak Steelmak. 2021. doi: 10.1080/03019233.2021.1915645. 
21. Fan $\mathrm{DQ}$, Sohn $\mathrm{HY}$, Elzohiery M. Analysis of the reduction rate of hematite concentrate particles in the solid state by $\mathrm{H}_{2}$ or $\mathrm{CO}$ in a drop-tube reactor through CFD modeling. Metall Mater Trans B. 2017; 48: 2677-2684.

22. Elzohiery M, Sohn HY, Mohassab Y. Kinetics of hydrogen reduction of magnetite concentrate particles in solid state relevant to flash ironmaking. Steel Res Int. 2016; 88: 1600133.

23. Elzohiery M, Fan DQ, Mohassab Y, Sohn HY. Kinetics of hydrogen reduction of magnetite concentrate particles at 1623-1873 K relevant to flash ironmaking. Ironmak Steelmak. 2021; 48: 485-492.

24. Fan DQ, Elzohiery M, Mohassab Y, Sohn HY. The kinetics of carbon monoxide reduction of magnetite concentrate particles through CFD modelling. Ironmak Steelmak. 2021; 48: 769-778.

25. Wang $\mathrm{H}$, Sohn HY. Effects of reducing gas on swelling and iron whisker formation during the reduction of Iron oxide compact. Steel Res Int. 2012; 83: 903-909.

26. Fan DQ, Sohn HY, Mohassab Y, Elzohiery M. Computational fluid dynamics simulation of the hydrogen reduction of magnetite concentrate in a laboratory flash reactor. Metall Mater Trans B. 2016; 47: 3489-3500.

27. Elzohiery M, Fan DQ, Mohassab Y, Sohn HY. Experimental investigation and computational fluid dynamics simulation of the magnetite concentrate reduction using methane-oxygen flame in a laboratory flash reactor. Metall Mater Trans B. 2020; 51: 1003-1015.

28. Elzohiery M. Flash Reduction of magnetite concentrate related to a novel flash ironmaking process. Salt Lake City, Utah: University of Utah; 2018.

29. Fan DQ. Computational fluid dynamics analysis and design of flash ironmaking reactors. Salt Lake City, Utah: University of Utah; 2019.

30. Abdelghany A, Fan DQ, Elzohiery M, Sohn HY. Experimental investigation and computational fluid dynamics simulation of a novel flash ironmaking process based on partial combustion of natural gas in a reactor. Steel Res Int. 2019; 90: 1900126.

31. Cho JH, Sohn HY. Effects of particle shape and size distribution on the overall fluid-solid reaction rates of particle assemblages. Can J Chem Eng. 2016; 94: 1516-1523.

32. Mcllvried HG, Massoth FE. Effect of particle size distribution on gas-solid reaction kinetics for spherical particles. Ind Eng Chem Fundam. 1973; 12: 225-229.

33. Kimura T, Ojima Y, Mori Y, Ishii Y. Reaction Mechanism in a Flash Smelting Reaction Shaft. In: The Reinhardt Schuhmann international symposium on innovative technology and reactor design in extraction metallurgy. Warrendale, PA: TMS (The Minerals, Metals \& Materials Society); 1986. p. 403.

34. Kemori N, Ojima Y, Kondo Y. Variation of the composition and size of copper concentrate particles in the reaction shaft. In: Flash Reaction Processes, Proceedings of the 1988 Center for Pyrometallurgy Conference. Rolla, MO: The Center for Pyrometallurgy; 1988. p. 47.

35. Themelis NJ, Wu L, Jiao Q. Some aspects of mathematical modeling of flash smelting phenomena. In: Flash Reaction Processes, Proceedings of the 1988 Center for Pyrometallurgy Conference. Rolla, MO: The Center for Pyrometallurgy; 1988. p. 263. 
JEPT 2021; 3(3), doi:10.21926/jept.2103042

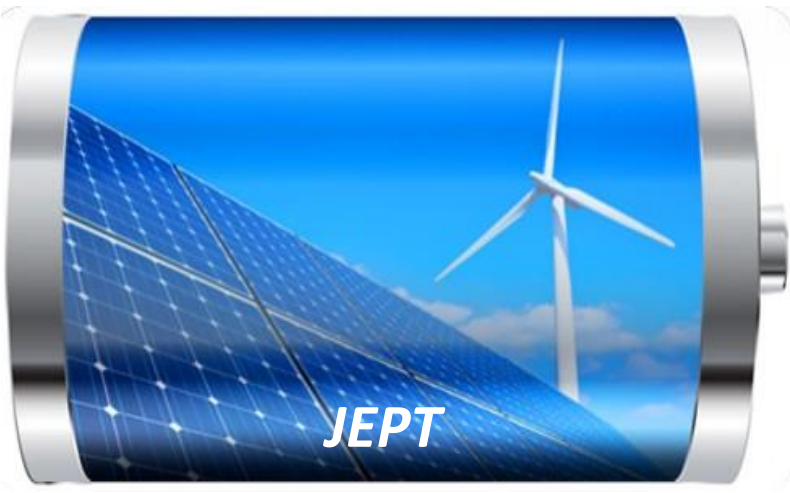

Enjoy JEPT by:

1. Submitting a manuscript

2. Joining in volunteer reviewer bank

3. Joining Editorial Board

4. Guest editing a special issue

For more details, please visit:

http://www.lidsen.com/journal/jept 